On being put to the meeting, $\mathrm{Dr}$. Johnstone's motion ras agreed to.

Each member present wrote on a slip of paper the name of the gentlemen whom he wished on the Committee, and after the scrutineers had handed in their report,

The Prasident said-There is practically a unanimons vote for Dr. Robertson and Dr. Oswald. Dr. Robertson and Dr. Oswald, along with the Honorary Secretary, will, therefore, form the Committee.

Dr. WATson, on behalf of those present, begged to thank the President for his interest in the work of the Branch, and for his presence on that occasion.

Dr. Nrcorson suitably replied, and the proceedings terminated.

The usual dinner then took place at the Palace Hotel.

\title{
MEETING OF THE SOUTH WESTERN DIVISION.
}

$\Delta$ meeting of the South Western Division was held at Wonford House, Ereter, on Tuesday, 15th October. 1895. There were present Dr. P. Maury Deas (who was voted to the chair), Drs. Morton, Aldridge, Weatherly, Felvus, Mortimer, Wilson, Davis, Wade, Benham, Aveline, and Macdonald (Hon. Sec.)

Dr. Dras, in welcoming the members, said this was the first meeting of the $\Delta$ ssociation ever held in Exeter, and he could only wish that there had been a larger attendance and that it had been a finer day. He felt it a privilege to do what little he could to make the gathering a pleasant one.

The minutes of the previous meeting were then read and confirmed.

LETTKR PBCX WRS. HACK TUKE.

The Honorary Secrirary read a letter from Mrs. Hack Tuke thanking the Division for their vote of sy mpathy and condolence. ELECTION OP NEW MEABERBS.

The Cratrmas declared that the following new members had been duly elected :-

Robert Leosard Rotheiryord, M.D., Medical Superintendent, Digby's Asylum, Exeter.

Wintiax Britan Morton, M.B., Assistant Medical Officer, Wonford House, Exeter.

ALlaN MacLean, M.D., J.P., St. Martin's, Weymouth.

MAURICE HowARD LAsLETT, L.R.C.P., Assistant Medical Officer, Somereet and Bath Asylum, Wells.

$\Delta$ discussion took place of which Dr. MACDONALD suggested that as far as possible the meetings should be held in the centre of the district. This found general acceptance. It was eventually decided to hold the next meeting on Tuesday, 14th April, 1896, at Gloncester.

REPORT OF THR COMMITTER ON CRIMINAL RESPONBIBICITY.

The Crarkxan said the Hon. Secretary had a report to make with regard to. a communication from the General Secretary.

Dr. MACDONaLD stated that he had received a copy of the report of the Committee on Criminal Responsibility, and also a letter from the General Secretary asking hin to bring the report before the Divisional Meeting. As this report came the day after the notice for this meeting went ont be of course could not bring it forward that day, aud perhaps it was better that he could not do so. He asked for instructions.

Dr. Wratraerly emphasised the views he expressed at the discussion upon the report at the last Annual Meeting of the Association (vide No. for Oct, 1895, p. 744), and referred to the resolution put from the chair on that occasion, and unanimously adopted. He earnestly hoped that, when this matter came up for discussion at their next meeting, they would be able to send up such 
a resolution to the Annual Meeting that this report would be put on the shelf for ever and a day.

The Cantryan-Is there any resolution on the subject The Secretary asks for instructions.

'Dr. Macdonald-I don't think we shall differ very much from what Dr. Weatherly has said. My idea is that this report should be the first item on the agenda at our next meeting, and that we; then discuss it. I move that this course be adopted.

Dr. Wratrancy having seconded, the Casiryan then put it to the meeting that the consideration of the report on criminal responsibility be placed first on the agenda for the next meeting, and this was agreed to nem. con. PAPERS READ.

Dr. Dras opened a discussion on mechanical restraint. (See page 102).

Owing to the limited time at the disposal of the members the Honorary Secretary's paper on the "Nursing Staff" was, with regret, again held over until the next meeting.

Dr. Mortos read notes on "Three Cases of Spontaneous Gangrene. (See page 119).

Dr. WADE said the very pleasing duty fell to him of proposing a resolution which, he was quite sure, would be carried by acclamation, namely a very hearty vote of thanks to Dr. Deas for his kind reception of them at Exeter. He was only sorry that, Exeter being at one end of the district, they had not had a better attendance; yet, indeed, he did not know that Exeter being at one end of the district had anything to do with it, because there were several members within a stone's throw who had not attended. He was afraid that with asylum life some of them got very fond of staying at home. That was a bad plan, and was a poor return for the hospitality shown them, and for the trouble their Honorary Secretary took to get the meetings together.

Dh BrevHAm had very great pleasure in seconding, and the motion was carried by acclamation.

. Dr. Dras suitably replied, and the meeting terminated.

The members afterwards dined together at the New London Hotel.

MEETING OF THE IRISH DIVISION.

A meeting of the Irish Division was held at the District Asylum, Limerick, on. Wednesday, the 23rd October, 1895.

The following members wiere among those present:-Dr, Bagenal Harrey (Clonmel), Dr. Nash (Limerick), Dr. C. Norman (Dublin), Dr. O'Mara (Limerick), Dr. O'Neill (Limerick), and Dr. Oscar.T. Woods (Cork), Honorary Secretary. Drs. Gelston and Shanahan, of Limerick, were present as guests.

On the motion of Dr. O' NerLl, Dr. Conolly Norman took the chair. FHECTION OF NEW MEMBERS.

The following gentlemen were duly proposed for election as members of the Association, and having been balloted for, were unanimously elected:-

James Cismen, M.B., B.Ch., B.A.O., R.U.I., 3rd A.M.O., Cork District Asglum.

John Francis Sranaean, L.R.C.P.I., L.R.C.S.I., 2, The Crescent, Limerick, Medical Officer of the Limerick Workhouse.

$$
\text { DR. O'NEILL'S PAPER. }
$$

Dr. O'Naruc read a paper on "The Systematic Employment of the Insane," which, together with the discussion, will be published in a future number of this Journal.

$$
\text { DR. O'MARA'S PAPER. }
$$

15. O'Mara read a paper on "Artificial Feeding." He was of opinion that artificial feeding should be resorted to when a patient remains 36 hours without. 